Jelena Čvorović

\title{
The making of the Gypsies: invention of traditions
}

\begin{abstract}
This paper attempts to assess the dilemma raised by anthropological discourse about the invention of traditions. Invented traditions are important symptoms and hence indicators of problems which might not otherwise be recognized, and certain developments which are difficult to identify and date. The Serbian Roma are selected to illustrate this phenomenon.
\end{abstract}

Key words: traditions, Serbian Gypsies, ethnic identity

\section{Introduction}

Inventing traditions, including nations and ethnicity, is a process of formalization and ritualization, characterized by reference to the past (Hobsbawm 1983). The actual process of creating such ritual and symbolic complexes has not been adequately studied-much of it is still rather obscure. The invention of tradition occurs more frequently when a rapid transformation of society weakens or destroys the social patterns for which "old" traditions had been designed. Within anthropology, and among critics outside the discipline, there is a suspicion that the invention of culture and tradition are a politically revisionist and anti-native queries (Linnekin 1991). The apprehension is that writing about the contemporary construction or invention of tradition undercuts the cultural authority of the studied peoples by calling into question their authenticity. In this sense, authenticity is equated with the transmission through time of a tradition (Handler 1986). The main problem is that the way the issue of invented tradition is represented and understood outside the anthropological discipline. Even when such invented traditions are revealed to be an intellectual ploy, the issue remains an emotional and political for the peoples studied, particularly for those who are engaged in a struggle for political recognition. This holds to be particularly true for the Roma/Gypsy ethnic/minority group in Serbia. The question is does anthropology, as one of the inventing instruments in the latest Roma inventionthe Egyptians and Ashkali cases- raise doubt that anthropological accounts do not represent cultural reality? This paper attempts to shed light on this question.

Етноантрополошки проблеми н.с. год. 1. св. 1 (2006) 
The Roma/Gypsies are probably of northern Indian origin, having moved out of that area some time between $800 \mathrm{AD}$ and $950 \mathrm{AD}$, and migrated westwards into Europe, arriving there some time after 1100 AD (Hancock 1987). It is unclear why they left India, and there are no explanatory written documents. From linguistic influences preserved in all Romani dialects, it is most likely that Gypsy major migration route passed through Persia, Armenia, Greece and the Slavic-speaking parts of the Balkans. A number of early European historical sources refer to the Gypsies as Egyptians, and the term "Gypsy" is thought to mirror that assumption (Fraser 1992). According to historical sources, the Gypsies themselves spread out the legend about their Egyptian origin; they represented themselves as dukes, kings and princes from Egypt. The inventive process of Gypsy traditions in Europe had begun: "In the entire chronicle of Gypsy history, the greatest trick of all was the one played on western Europe in the early $15^{\text {th }}$ century" (ibid.:62). Gypsies/Roma had begun their sojourn in Europe by taking advantage of the Christian piety of the age. Since it was a Christian obligation to help pilgrims, especially the ones with documents of recommendation from rulers, the Gypsies created letters of passage from high government officials such as King Sigismund of Hungary, representing themselves as penitents for the sins of their ancestors who had rejected Christian teachings in Egypt. As a result of the sins of their ancestors, they were required to wander the earth as pilgrims seeking charity from others (Fraser 1992, Djordjevic 1932).

Today, linguistic and historical data, supported by new genetic studies, suggest that the European Gypsies, embracing a large number of socially different endogamous groups, may be a complex conglomerate of founder populations that originated in India (Kalaydjieva et al. 2001). Genetic results suggest a limited number of related founders, compatible with a small group of migrants splitting from a distinct caste or tribal group.

Individual Gypsy groups can be classified into major metagroups: the Gypsies of East European origin; the Sinti in Germany and Manouches in France and Catalonia; the Kaló in Spain, Ciganos in Portugal and Gitans of southern France; and the Romanichals of Britain (Fraser 1992). Out of these, the greatest variety is found in the Balkans, where numerous groups with well-defined social boundaries exist (Marushnikova\& Popov 1997).

The Gypsy and non-Gypsy populations have lived side by side in Europe for centuries and the experience was less than satisfying for all concerned. In spite of their presence in Europe for centuries, their integration into European society is poor. At the same time, they are one of the rare ethnic groups who never laid claim to a territory.

The present study of invented traditions cannot be separated from the wider study of the history of society. The position of Gypsies in Central and Eastern Europe is more or less the same. In Central and Eastern Europe the

Етноантрополошки проблеми н.с. год. 1. св. 1 (2006) 
policy of socialist governments was to assimilate Gypsies and for decades they were targeted for low-skilled employment within centrally planned economy (Crowe 1996). The idea was to create one culture, European in form, into which Roma would be successfully assimilated. Efforts were made to help Gypsies to settle down and to improve their economic and cultural position in the post-war years. This resulted in the banning of nomadism in most of the countries in the region, and destruction of Gypsy traditional occupations. And while protected to some extent by socialist regime, during the transitions period Gypsies became the biggest losers. Thus they have high levels of unemployment, substandard housing, lack of education and skills and a deepening dependence on state benefits and services. In Serbia, the transition started at a time when economy was near or at the collapse, and as a result, impoverishment and unemployment significantly rose, especially among Gypsies. On the other hand, due to the assimilation processes and manipulation with their ethnicity by the Roma themselves, many Roma today deny their Roma ancestry. Firstly, not all Roma people refer to themselves as Roma. Some prefer the European term cigani or zigeuner. Secondly, some European groups/tribes of Roma reject all together the connection with Roma people in general, like the Sinti and Manouches (Mirga \& Mruz 1997). This is perhaps particularly true for Serbian Roma, where many Roma refer to themselves as to "smoked Serbs", or just Serbs.

\section{Background}

Anthropologists have became acutely aware in recent decades that "culture" and "tradition" are anything but stable realities handed down intact from generation to generation. Tradition, for instance, is now understood to be an invention designed to serve contemporary purposes: "to read the present in terms of the past by writing the past in terms of the present" (Lindstrom 1982:317, cited in Hanson 1989:890). When a particular group invents its own traditions is it usually to legitimate or sanctify some current reality or aspiration. When, on the other hand, people invent traditions for others, and treat them as their inventions were the actual state of affairs, the invention of tradition for subordinate peoples becomes a part of the asymmetrical relationship of power (Hanson 1989). The Roma/Gypsy ethnic traditions form an excellent context in which to situate these issues. The invention of Ro$\mathrm{ma} /$ Egyptian/Ashkali ethnicity had been going on for a few decades, taking various forms in that time, and anthropological interpretations and misinterpretations have joined the contributions of other scholars, government officials and Roma themselves in the inventive process.

Етноантрополошки проблеми н.с. год. 1. св. 1 (2006) 


\section{Discussion}

Today, Gypsies are perhaps the most segregated ethnic group in Europe. The same is probably true for Serbia. In Serbia, Gypsies form a complex mixture of groups. In fact, there are a quite few subgroups of Gypsies in Serbia. Some of them lost the Romani language and their mother tongue is now Serbian. There are different forms of Romani depending on which group the Gypsy belongs to. Interaction between different groups is limited, and the form of Romani spoken is an important means of distinguishing between groups (Cvorovic 2004). Furthermore, Gypsies have always come under several appellations and names. Each group represents a historical and originally to a certain extent, localized entity. Gypsies always depended on the needs and contacts with their host countries, as a source of their livelihood; many times Gypsies adopted their hosts' culture in response to the different requirements of their social and environmental surroundings. The result is the great diversity of Gypsy tribes and the lack of identity as of an integrated ethnic group. Therefore, Gypsy culture in general is extremely diverse and difficult to pinpoint. Their ethnicity is also disputed and complex issue, coming from the fact that most Gypsies do not consider themselves members of a unified group, but identify instead with the subgroup to which they belong (Cvorovic 2004). Within these subgroups, language and religion also remain diverse; the religion which a Gypsy tribe or ethnicity might hold on is to depend on location and circumstances. A significant characteristic of Gypsies as a group is their adaptability to religious and political changes. Their religious and political standings depended always on the current political climate. For example, some contemporary Christian Gypsies are ex-Muslims.

Until very recently, the characteristic of all groups was that they did not mix up with each other-there appeared to be a strongly emphasized antagonism among the groups. A system that divides these groups, much like a caste system, still exists in some parts of Serbia today. In the past, with respect to other Gypsies, allowable marriage choices were largely restricted. Females in particular, were expected to marry someone within their particular tribe and most obeyed the rule by marrying within their group (ibid.).

In Serbia, the characteristic of the Gypsy as an ethnic group is so called "ethnic mimicry" or "favored identity", by which Gypsies declare themselves members of the majority community. According to 1991 census, there were 140,237 Roma/Gypsy in Serbia, which is $1.4 \%$. Today, an official estimates of Serbia's true Gypsies range between 360-500,000, compared to 7,478,820. Serbs (Save the Children 2001). On the other hand, many Roma consider themselves to be Serbs, belonging to a specific Roma/Gypsy subgroup. For example, the president of one local Roma association in the village of Macvanski Pricinovici, in Macva, comments:

Етноантрополошки проблеми н.с. год. 1. св. 1 (2006) 
We just got a status of national minority from the officials. Some asked for it, and got it. I haven't. We were Gypsies/cigani before, now we are Roma. I don't care. I'm a Serbian cigan and Serbian cigan I will stay. But now we have the title: Roma.

Another informant from the same village, who declare himself as Roma, argues:

The word Rom means a man, but for me, it actually means that you should not be ashamed to say that you are a Rom/cigani. On the other hand, we say that we are Roma, but we live together with out peasants [Serbs], we have the same customs and the same religion, and the only thing that differs us, is our face color! (Čvorović 2004: 111).

The "favored identity" matter is evident from the following statement of a Karavlax Gypsy, from the village of Drenovac, also in Macva:

I am a $100 \%$ original Serb. My father, and his father, and my grand-grand father were all born in Serbia. They always behaved like Serbs. I'm the same way. I don't know where my ancestors came from, but I feel I belong here. Never in my life I have felt like a Gypsy, not even for a moment. I have the same soul [like Serbs], the same blood, the same upbringing, the same everything. I declared myself as a Serb, on all censuses. The same is for my family: we all feel the same. We don't speak Gypsy language; we don't even know a one word of it. We only speak Serbian, and we know some Romanian, but it's a dialect with around $30 \%$ of Serbian words. The others are Roma, not us (Čvorović, 2004: 136).

Yet another variant of the Gypsy "favored identity" is the construction of the new ethnic identities and new traditions. Among Gypsies, these new identities and traditions assume to restore an ancient origin, in spite of the complexity to attest its legality and even obvious contradictions to historical records. A notorious example of the invented tradition and change in the identity of the ethnic group usually called Gypsies is the emergence of the Egyptian community in Serbia and Kosovo.

In fact, the Egyptians in various regions in the Balkans were known under various names: Jedjupci, Gjupci, Egjup, Adjupci, or Jevg, for example (Djordjević 1932, Vukanović 1983)). These various appellations were used for Muslim Roma ethnic groups in Serbia, Kosovo, Macedonia and Montenegro. In Montenegro, for example, their terms are connected with their traditional occupations: they are also known as Kovaci (Blacksmiths) or Ashkali (charcoal-burners) in Kosovo, the occupations traditionally reserved for the Roma in Balkans. In time, most of these local groups have lost their Romani language and heritage, and accepted the language and customs of the surrounding majority.

The term "invented tradition" here includes traditions actually invented, constructed and formally instituted, emerging in a less traceable manner within a brief and datable period (Hobsbawm 1983). The whole process of publicly establishing a new identity of the Egyptians came to the surface in th- 
e 1970s; in the 1991 census for the former Yugoslavia, the Egyptians are mentioned and noted for the first time. The census data reveals there are around 6.355 Egyptians. However, according to the 1995 Egyptian internal census there were around 85.000 of Egyptians in Kosovo (Zemon 2001). In 1999, at the onset of NATO bombing, during the peace-talk in Rambouillet an Egyptian named Abazi, a member of the Serbian delegation argued:

There are around 150.000 Egyptians in the Kosovo area today. We don't know the Romani language, but use only Albanian. Our children attend Albanian schools. We don't mix with other nations or with Roma. We don't celebrate Djurdjev-dan. Many centuries ago, the Turks have moved us from Egypt to Kosovo (V. Nedeljković 2002).

Soon, the Egyptians established themselves as a separate, though "imagined" community (Anderson 1996). Actually, the key element in their identity is the question of their ethno- genesis. Several scholars have joined their efforts with those of Egyptians leaders to make up a distinctive interpretation of historical documentations that serve as the foundation of the creation and development of this particular community (see S. Nedeljković 2003, Marashuikova et al. 2001, Zemon 2001, Courthiades 1999). Their connection with Egypt is allegedly justified by historical data. As mentioned before, the first Roma/Gypsies to arrive in the early $15^{\text {th }}$ century in Western Europe all claimed to be counts, dukes or even kings from "Little Egypt", and therefore, their names of Gypsies, Gitanos of the Greek Guftoi, all derived from the Egyptian name (Djordjević 1932, Fraser 1992). The particular "Egyptian" myth is traced down to Moldon, where a hill near the Western Greek town was called Gyppe, from Egypt, and was allegedly settled by Gypsies/Roma. However, the region was always known for its Roma settlements but never for "true" Egyptians who could have settled there under Ottoman domination. Moreover, the Arabic language was never spoken in the Balkans (Laederich 2000). Nevertheless, folk stories about ancient Egypt origin still live in oral traditions even among some Roma groups today, who are well aware of their India origin. For instance, the Gurbeti Gypsy group from Draginje in Macva declares themselves to be Roma: they acknowledge the fact that their ancestors came from India. However, these Gypsies/Roma trace back the origin of their Djurdjevdan celebration to ancient Egypt. According to their oral tradition, St. George was an Egyptian soldier, who killed a dragon and saved one Roma community in ancient Egypt (Cvorovic, in preparation).

Meanwhile, the struggle to establish and maintain the Egyptians as a separate community took various forms. Various associations, parties and foundations are established for this purpose. Many of their recently established cultural associations and clubs bear the names like "Pyramid", "Little Egypt", "Nefertiti" and so on (Zemon 2001). At the same time, various media have developed for the same purpose: magazine and journal publications, scientific and

Етноантрополочки проблеми н.с. год. 1. св. 1 (2006) 
pseudo- scientific books attempted to establish and cement the Egyptians folklore and "ancient" history. Also, many symbols related to ancient Egypt, like the photographs of Pharaohs, Cleopatra or pyramids are being displayed during gatherings as a confirmation of their true identity (S. Nedeljković 2003). In the meantime, the Egyptian leaders and scholars still struggle to influence and convince the wider community, as well as the Egyptians themselves that "...among this [Egyptians] ethnic community, there is an ethno-psychological self-confidence of belonging to a collective ethnic entity, different than other surrounding ethnicities...This [Egyptian] ethno-psychological self-confidence is taken to be...the most important ethnical category which speaks about the distinctiveness of one community" (Zemon 2001: 66-67, my translation).

And while the Egyptian elite tries to distance and repel from the Roma ethnic group, many of "the Egyptians" perceive themselves as Roma: they consider themselves to be Roma, they speak Romani language, and some even participate actively in various Roma associations (S. Nedeljković 2003, P. Polansky $^{1}$ 2003, personal communication). Some, on the other hand, declare themselves to be Albanians, Macedonians or Turks, depending on the circumstances and current political climate. In fact, the Egyptians speak the languages of the surrounding populations. In Kosovo, for instance, their native language is Albanian, but they use Romani and Turkish almost equally; in Macedonia and Serbia, they speak Albanian and Serbian. Furthermore, in spite of the allegedly encouraged endogamy, the Egyptians all freely intermarry other "ethnic" groups: in Kosovo, they intermarry with Roma and Ashkali (Laederich 2000, P. Polansky, p.c., May 2003).

Nonetheless, in spite of the efforts of the Egyptian elite, the ethnic identity of the Egyptians is still rather depleted and uncertain of its memberships values and obligations. However, in time and with enough of repetition of the invented traditional elements, political and media pressures and encouraged endogamy, these elements may become "a real" ethnical symbols for the Egyptians.

Following the Kosovo war, after the former Yugoslavia was confound and the territory was handed over to ethnic Albanians, yet a new minority emerged: the Ashkali. Many scholars identify the Ashkali group as Albanian speaking Roma (P. Polansky, p.c., 2003, V. Nedeljković 2002, Vukanović 1983). In the past, the name "Ashkali" was used to assign the Roma ethnic group in southern Serbia and Kosovo; they were Muslim Gypsies, who gradually lost their Romani language and adopted the language and customs of the Albanian minority (Vukanović 1983:138). Their traditional occupations included blacksmithing and coppersmithing. Today, most Roma from Kosovo consider the

\footnotetext{
${ }^{1}$ An American author and Gypsy rights activist who has lived with Eastern European Roma (including Kosovo Roma) for more than 10 years.
}

Етноантрополошки проблеми н.с. год. 1. св. 1 (2006) 
Ashkali as well as the Egyptians to be Albanian speaking Roma (P. Polansky, personal communication); according to the Egyptians, the Ashkali are pure Egyptians who deliberately hid their identity, and the word "ashkali" comes from an Albanian word for charcoal (see also Marushiakova et. al 2001). Yet, following the Egyptian example, the Ashkali managed to found a political organization, by which they declared their separate ethnic identity. They claim that there are around 200.000 of Ashkali in Serbia, of whom majority is displaced from Kosovo after the war. The Ashkali in Serbia explicitly stated that they are not Roma/Gypsies, nor Albanians, but a native people from Kosovo, with its own language that only resembles Albanian (V. Nedeljković 2001). The Kosovo Ashkali, on the other hand, states that they came from Egypt; some of them call themselves Hashkali. Thus, they claim that this name was given to them by the Kosovo Roma. Today, they live mostly in Albanian villages, in their own mahallas and follow mainly Albanian customs. In fact, most know their ancestors were Roma, but in their scramble to survive and avoid retaliation and discrimination against the Roma, the Ashkali now deny their Roma roots (P. Polansky, p.c.). In Kosovo, like the Roma themselves, they try to live without working, surviving on pensions and social assistance. The Ashkali community produced several versions of their ethno-genesis and history, based allegedly on their oral traditions and folklore. The basic purpose of creating and inventing this new tradition was probably to distinguish themselves from other Roma and Egyptians. According to one legend, they came originally from Iran, arriving in the Balkans around the $4^{\text {th }}$ century AD. The Askhali adopted the Illyrian language, while the Illyrians adopted the religion of the Ashkali themselves-Islam (Marushiakova et. al 2001). Another legend holds the Ashkali to be the colonists from ancient Rome, who came from Italy to Albania, and this is why they speak the Albanian language. There is a third legend, too: the Ashkali originated in Askalon, in Biblical Palestine; therefore, the Ashkali originated at most ancient times and relate their name, civilization and culture to another Biblical nation.

The appearance of new communities among Roma is still an on-going process, and one cannot predict how many more will originate in the future. The emergence and existence of the present communities is unique inasmuch as external play has been involved in the "creation" of those new identities. In the former Yugoslavia the beginning of the transition period brought about ethnic competition and conflict that resulted in a decade of wars; during the war and post-war years, in a situation of general ethnic factionism, the Egyptians and Ashkali came out. Before the Kosovo war, the Egyptians and Ashkali declared themselves mostly as Albanians. With the escalation of conflict between on one side Serbia and Macedonia, and on the other, ethnic Albanians, the Albanian speaking Roma emerged as two separate groups. The Serbian and Macedonian officials supported the creation and separation of these gro-

Етноантрополочки проблеми н.с. год. 1. св. 1 (2006) 
ups out of Albanian national minority: the emergence corresponded with their own political and national interests (S. Nedeljković 2003).

Many of the Roma leaders, on the other hand, resist the emergence of the Egyptians and Ashkali, and actually see this phenomenon as a separatism that weakens the already loose unity of their national minority. One of the Roma leaders in Serbia, Dragan Vasiljkovic, the president of the Roma Union of Western Serbia, argues:

I take them [the Egyptians and Ashkali] to be Roma people. There is no proof that they originated in Egypt, or that they represent a different ethnic entity. What their leaders claim-is just a theory, without any historical evidence and connection. In fact, this is a calculated manipulation in order to avoid and deny their Roma roots, combined with the personal interests of their leaders. Just a decade ago, those same leaders were actively involved in our Roma movement, and today, they declare themselves to be a separate ethnic group- whether the Egyptians or Ashkali (personal communication, May 10, 2003).

\section{Conclusion}

The emergence of the Egyptians in Serbian territories is a striking example of the so-called "invented tradition". In the case of the Egyptians, it emerged within a few decades and established itself with great rapidity. The Egyptian newly emerged "ethnic" tradition seeks to infuse certain values and norms of behavior by recurrence, which repeatedly implies continuity with the past. Here, the ethnic group attempts to establish continuity with a suitable historic past. Their invented tradition serves to establish a social cohesion or the membership of a real or artificial group or a community. The producers of such inventions are outsiders as well as insiders: anthropologists often participate in the creative process. On the other hand, the existence of such invented traditions damage the hierarchy and unity among Roma. Hierarchy, which promotes cooperation and reduces competition, is not only the basis of a group/society wealth; it is also the basis of success in competition with outsiders (Steadman 1997).

Therefore, the question of "genuine" vs. "invented" tradition among Roma raises some important questions. The logic of cultural invention implies that anthropological knowledge is available to various contending parties, to use in pursuit of their own ends (Linnekin 1991). However, political reading of the issue arises when cultural/tradition invention is explored in contemporary nationalist contexts, for in such situation cultural authenticity is seen as the legitimating merit of group identity: continuity with the past is taken as a test of validity and genuineness about cultural identity (Clifford 1988). What anthropology could see as an advance in cultural theory, could be interpreted, on the other hand, as damaging to native claims to cultural distinctiveness. Conver-

Етноантрополошки проблеми н.с. год. 1. св. 1 (2006) 
sely, the question remains open: "should we avoid writing about cultural invention as a process, about nationalism, or only about cultural invention in nationalist contexts?" (Linnekin 1991:448). If we take Clifford's (1988) stand that culture is an ongoing human creation, than, in the case of Serbian Roma, the invention of traditions could be seen as the symbolic construction of social life. In cross-cultural research, an "ethnic unit" or a cultunit is usually defined by language, political organization, and territorial contiguity (Abruzzi 1982:15). However, in Serbia various Gypsy groups are divided today on the basis on the language used, they have no common territory and their community organization varies region to region. Within an ecological approach, an ethnic population/group is defined as an assemblage of individuals with a significant number of behavioral characteristics shared, a shared historical identity and a higher occurrence of marriage with members of the same population than with members of other populations (Abruzzi 1982:16). Among these, marriage is of a central importance in the definition of ethnic populations: ethnic endogamy preserves the distinctive ethnic characteristics within a community. The extent of ethnic endogamy functions as isolating mechanism by enhancing ethnic identity and reproductive isolation of the population (van den Berghe 1979). Furthermore, ethnic endogamy also preserves and maintains the adaptive traits like reproductive and subsistence strategies, access to resources, or child-rearing practice. Since selection for ethnic differentiation operates upon learned behavioral patterns, the more such isolating mechanisms become institutionalized, as part of the explicit rules of a community, the greater is the likelihood that they will be maintained in that community in the following generations. The stereotypes of behavior are likely to lead to socially adaptive, appropriate behaviors a large portion of time (Wilson 2000, Daly and Wilson 1983).

Among Gypsies, it is possible that the division into small groups has occurred due to the pressure in the face of competition for resources and territory, and has been consolidated further by oppressive legislation and maltreatment, geographic dispersal and cultural and linguistic divergences. The Gypsy particular occupation created the local kin group individuality, along with the particular "invented" tradition. Gypsies became more accepted/tolerated in places where their particular occupation was in need. Therefore, it was perhaps the local group intention to preserve the particular occupation and tradition, by not mixing and not creating wider kinship and marriage ties with Gypsies in other regions, especially if they were from a different group. In this sense, when an ethnic group-Gypsies-became endogamous on the local level, they became almost identical to tribes, whose identification is distinguished by common ancestry. Individuals in a tribe assume they are a set of co-descendants, and given the regular occurrence of marriage through time within that set, the assumption is surely true (Steadman 1992). A tribe, or an "ethnic" lo-

Етноантрополочки проблеми н.с. год. 1. св. 1 (2006) 
cal Gypsy group may be also culturally distinctive: their clothing and language may communicate their ancestry, and their family names often indicate their "ethnic"/local identity. Such features are used by individuals involved to identify genealogical distance, and on the basis of which they may systematically discriminate and favor members of their own group over outsiders (ibid.). Gypsy traditions therefore, reflect up to date concerns and purposes rather than a passively inherited legacy.

The current invention of Roma/Egyptians/Ashkali traditions is becoming more and more built-in into those cultures by reason of people talking about them and practicing them. In Serbia, Gypsy culture is an issue in the struggle: "Inventions are common components in the ongoing development of authentic culture...invention is an ordinary event in the development of all discourse" (Hanson 1988:899).

\section{References}

Abruzi, W.S. 1982. Ecological theory and ethnic differentiation among human populations. Current Anthropology, 23, 1:13-24.

Anderson, B. 1996. Imagined Communities. Reflections on the Origin and Spread of Nationalism. London. New York: Verso.

Barth, F. (Ed.). 1969. Ethnic Groups and Boundaries. The Social Organization of Culture Difference. Boston: Little Brown.

Clifford, J. 1988. The Predicament of Culture. Cambridge, MA: Harvard University press.

Crowe, D.M. 1996. A History of the Gypsies of Eastern Europe and Russia. New York: St. Martin's Griffin.

Courthiades, M. 1999. Towards a Typology of Balkan National Communities: Non-territorial Groups. Unpublished manuscript.

Cvorovic, J. 2004. Sexual and Reproductive Strategies among Serbian Gypsies. Population \& Environment.Vol 25(3) : 217-242.

Čvorović, J. 2004. Gypsy Narratives: From Poverty To Culture. The Institute for Ethnography, Serbian Academy of Sciences and Arts.

Daly, M. \& Wilson, M. I. 1983. Sex, Evolution, and Behavior. Belmont, CA: Wadsworth Publishing Company.

Djordjević, T. R. 1932. Naš narodni život i običaji. Knjiga VI. Beograd. Književna Zadruga.

Fraser, A. 1992. The Gypsies. Cambridge: Blackwell.

Hancock, I. 1987. The Pariah Syndrome: an Account of Gypsy Slavery. Ann Arbor, MI: Karoma Publishers.

Handler, R. 1984. On Sociocultural Discontinuity: Nationalism and Cultural Objectification in Quebec. Current Anthropology XX, 25:55-71.

Handler, R., \& Linnekin, J. 1984. Tradition, Genuine or Spurious. Journal of American Folklore, 97:273-290. 
Hanson, A. 1989. The making of the Maori: Culture Invention and its Logic. American Anthropologist, 91: 890-899.

Hobsbawn, E. 1983. In Hobsbawn, E. \& Ranger, T. (eds.). The Invention of Tradition, pp. 1-14. Cambridge: Cambridge University Press.

Kalaydjieva L, Calafell F, Jobling MA, Angelicheva D, de Knijff P, Rosser ZH, Hurles M., E, Underhill P, Tournev I, Marushiakova E, Popov V. 2001. Patterns of interand intra-group genetic diversity in the Vlax Roma as revealed by $\mathrm{Y}$ chromosome and mitochondrial DNA lineages. European Journal of Human Genetics, 9(2):97104.

Laederich, S. 2000. Roma, Ashkali, Egyptians. A Kosovo Peculiarity. www.romnews.com/kosovo.html

Marushiakova E., \& Popov, V. 1997. Gypsies (Roma) in Bulgaria. Peter Lang, Frankfurt am Main.

Mirga, A. \& Mruz, L. 1997. Romi, razlike i tolerancije. Beograd: Akarit.

Nedeljković, S. 2003. Etno-antropološke dileme u više dimenzija: Egipćani u Beogradu. Tradicionalno i savremeno u kulturi Srba, posebna izdanja, EI SANU 49, Beograd : 309-328.

Nedeljković, V. 2002. Svaka sličnost nije slučajna. Iskra, 1. maj.

Save the Children 2001. Denied A Future? The Right to Education of Roma, Gypsy and Travelers Children. Save the Children Fund. United Kingdom.

Steadman, L.B. 1992. Kinship, religion and ethnicity. Paper presented at meeting of $\mathrm{Hu}$ man Behavior and Evolution Society. Albuquerque. NM.

Steadman, L. B. 1997. Kinship Hierarchy: the basis of cooperation? Paper presented at meeting of Human Behavior and Evolution Society. Tucson. AZ.

van den Berghe, P.L. 1979. Human Family Systems. An Evolutionary View. New York: Elsevier Press.

Wilson, E.O. 1975/2000. Sociobiology: the New Synthesis. Cambridge, MA: Harvard.

Zemon, R. 2001. Balkanski Egipćani. Istina o Egipćanima sa Kosova i Metohije.Beograd: Nacionalna zajednica Egipćana Kosova i Metohije.

Етноантрополошки проблеми н.с. год. 1. св. 1 (2006) 
Jelena Čvorović

Stvaranje romskih etničkih grupa: zamišljanje tradicija

Stvaranje i zamišljanje tradicija, nacija i etničkih grupa ne predstavlja novi problem $\mathrm{u}$ antropologiji kao nauci: takav kreacionizam potpomognut od strane antropologa $\mathrm{i}$ ostalih naučnika i proučavanih zajednica postoji od kada postoji i antropologija, a ipak takvi procesi ostaju nedovoljno proučeni. Najveći problem zamišljenih tradicija/kultura je predstavljanje i razumevanje takvih tradicija van naučnih disciplina: kada određena grupa izmisli sopstvenu tradiciju, uz pomoć drugih koji nisu deo te određene grupe, izmišljena tradicija neminovno postaje deo asimetričnih odnosa moći. Etničke tradicije Roma/Cigana predstavljaju dobar kontekst u kojem se ovakvi procesi mogu proučavati. Romi su prisutni u Evropi još od srednjeg veka, te se tako mogu nazvati jednim od evropskih naroda. Romske i ne-romske populacije su živele jedne pored drugih tokom nekoliko vekova, ali je obostrano iskustvo više nego nezadovoljavajuće. Etnicitet Roma je postao veoma složeno i osporavano pitanje zahvaljujući, pre svega, društvenim i sredinskim uslovima koje su Romi zatekli po dolasku u Evropu, naročito na Balkanu. Većina Roma se danas ne smatra pripadnicima jedne ujedinjene i homogene etničke grupe, već se identifikuje sa podgrupom-plemenom iz koje potiče, a čija religija i jezik najviše zavise od lokacije i okolnosti. Ne postoji jasna svest o jedinstvu romskog naroda: mnogi Romi ne nazivaju sebe Romima, i odbijaju svaku vezu sa romskih narodom. Etnička mimikrija i izmišljeni (preferirani) identitet karakterišu romsku populaciju u Srbiji. Konstrukcija novog etničkog identiteta i nove tradicije često je u suprotnosti sa istorijskim podacima, ali to nema nikakvog uticaja na formiranje i prihvatanje ovih novih identiteta, kako od strane samih Roma tako i od strane međunarodnih činilaca. Notorni primer ovakve izmišljene tradicije je pojava egipćanske zajednice u Srbiji i na Kosovu. Kreiranje identiteta Roma Egipćana počelo je pre nekoliko decenija, uz pomoć naučnika različitih profila, slobodnih antropoloških interpretacija, zvaničnika i samih Roma. Najvažnije pitanje za antropologiju tako postaje pitanje kulturne realnosti i interpretacije antropoloških podataka.

\section{Jelena Čvorović}

Façonner les Gitans: invention des traditions

Le présent article représente une tentative d'aborder un problème soulevé dans le discours anthropologique : celui de l'invention des traditions. Les traditions inventées représentent des symptômes importants: ce sont des indices qui permettent de cerner des problèmes qui n'auraient pu être identifiés autrement, et de repérer certains développements qu'il aurait été difficile de reconnaître et situer dans le temps. La population rom de Serbie a été choisie pour illustrer ce phénomène. 